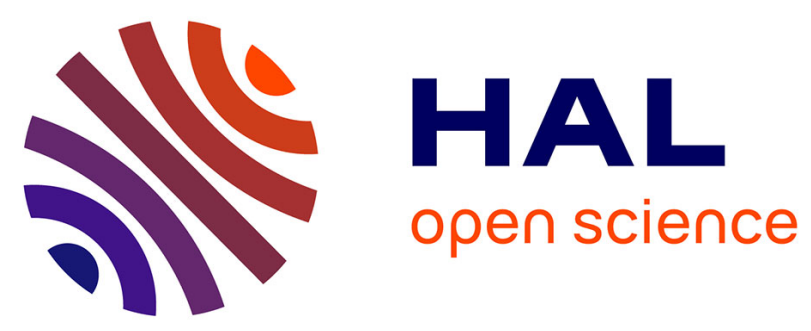

\title{
What lessons can be learned about asthma phenotypes in children from cohort studies?
}

Jocelyne Just, Flore Amat, P Saint-Pierre, R Gouvis-Echraghi, N Guillemot, T Guiddir, R Couderc, Isabella Annesi-Maesano

\section{- To cite this version:}

Jocelyne Just, Flore Amat, P Saint-Pierre, R Gouvis-Echraghi, N Guillemot, et al.. What lessons can be learned about asthma phenotypes in children from cohort studies?. Pediatric Allergy and Immunology, 2015, 26 (4), pp.300-305. 10.1111/pai.12359 . hal-01166988

\section{HAL Id: hal-01166988 \\ https://hal.sorbonne-universite.fr/hal-01166988}

Submitted on 23 Jun 2015

HAL is a multi-disciplinary open access archive for the deposit and dissemination of scientific research documents, whether they are published or not. The documents may come from teaching and research institutions in France or abroad, or from public or private research centers.
L'archive ouverte pluridisciplinaire HAL, est destinée au dépôt et à la diffusion de documents scientifiques de niveau recherche, publiés ou non, émanant des établissements d'enseignement et de recherche français ou étrangers, des laboratoires publics ou privés. 
1 What lessons can be learned about asthma phenotypes in children

$2 \quad$ from cohort studies?

3 J Just ${ }^{1,2}$, F Amat $^{1,2}$, P Saint Pierre $^{3}$, R Gouvis-Echraghi ${ }^{1}$, N Guillemot ${ }^{1,2}$, T

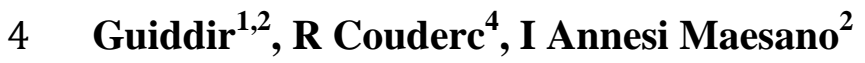

5

$6{ }^{1}$ Allergology department, Centre de l'Asthme et des Allergies. Hôpital d'Enfants

$7 \quad$ Armand-Trousseau (APHP) -

$8 \quad{ }^{2}$ Sorbonne Universités, UPMC Univ Paris 06, UMR_S 1136, Institut Pierre Louis

9 d'Epidémiologie et de Santé Publique, Equipe EPAR, F-75013, PARIS 75571 Cedex

$10{ }^{3}$ Laboratoire de statistiques théoriques et appliquées, Université Pierre et Marie Curie -

11 Paris 06, 4 place Jussieu, 75252 PARIS cedex 05, France.

$12{ }^{4}$ Service de biochimie et biologie moléculaire, Hôpital d'Enfants Armand-Trousseau -

13 26, Avenue du Dr. Arnold Netter, 75571 PARIS Cedex 12 - UPMC Univ Paris 06.

14 France.

15 Word $(4780 / 4500)$

$16 \operatorname{Ref}(43 / 75)$

19 Address for correspondence:

20 Pr. Jocelyne JUST

21 Centre de l'Asthme et des Allergies. Hôpital d'Enfants Armand-Trousseau (APHP) -

22 26, Avenue du Dr. Arnold Netter, 75571 PARIS Cedex 12. France.

23 Tel. +33144736317 
$24 \quad$ Fax: +331447366 35

25 E-mail: jocelyne.just@ trs.aphp.fr

26

27 


\section{Abstract}

29 "Phenotyping" asthma by multivariate analyses and more recently by unsupervised

30 analysis has been performed in children cohorts. We describe the key findings that

31 have emerged from these cohorts. In very young children 3 wheeze phenotypes seem

32 to exist: the mild episodic viral wheeze phenotype, thesevere atopic wheeze and more

33 inconstantly encountered the severe nonatopic wheeze. Early onset of allergy in

34 asthma (more frequently encountered in boys) is associated with poor prognosis unlike

35 the severe non-atopic wheeze phenotype with a female predominance. The prognosis

36 of the severe nonatopic wheeze depends on time of onset (early or late) of allergic

37 expression. At school age, the risk of severe asthmatic exacerbations is associated with

38 eosinophil predominant inflammation frequently related to allergic asthma, whereas

39 neutrophil inflammation is associated with moderate-to-severe asthma with poorer

40 lung function. Nevertheless, Allergic asthma is also a heterogeneous disease with

41 severe allergic phenotype strongly associated with with atopic dermatitis and very

42 high eosinophil-driven inflammatory markers. Further studies are required to find non-

43 invasive biological markers to better define wheezing phenotypes in very young

44 children associated with an elevated risk of developing severe asthma with a view to

45 personalizing treatment. 


\section{Introduction}

48 Asthma is the most common disease during childhood. It affects $200-300$ million

49 people worldwide, and its prevalence has increased over the past few decades ${ }^{1}$.. It is a

50 heterogeneous disease in terms of triggers, severity, inflammation and age of onset ${ }^{2}$.

51 To date, asthma classification has mainly been related to asthma severity: it is

52 generally accepted that phenotypes related to asthma severity follow a track during

53 childhood and even during the whole of life ${ }^{3}$. This observation supports the notion that

54 phenotypes defined by asthma severity remain stable.

55 Asthma severity is also an important parameter because the major healthcare burden of

56 this disease is related to severe asthma. Nevertheless, severe asthma includes multiple

57 features and it is important to distinguish between the different severe phenotypes to

58 determine targeted and effective treatment ${ }^{4}$.

59 Anti-inflammatory treatment is the pedestal of asthma treatment but there is ongoing

60 debate about whether children, especially preschool children, should be treated with

61 continuous or intermittent inhaled corticosteroid treatment. On the other hand,

62 uncontrolled asthma despite high levels of controlled medication should be treated

63 with an additional treatment such as an anti- $\operatorname{IgE}^{5}$ or various anti-cytokine treatments.

64 There is currently growing evidence that personalized medicine based on phenotypes

65 and endophenotypes (characterized by physiopathological pathways) is important in

66 the management of all chronic diseases ${ }^{6}$ For all these reasons, and especially to

67 contribute to decreasing the burden of the disease, phenotypes deserve to be described

68 in asthma.

69 Against this background of "phenotyping" asthma, multivariate analyses and, more 70 recently, unsupervised analyses have been performed in birth cohorts ${ }^{789101112131415}$. In the same manner, phenotyping analyses have also been performed in cohorts of 
72

children comprising moderate to severe asthma phenotypes ${ }^{1617181920212223}$. In relation to

73 these data, it appears that age of onset, hyperresponsiveness, asthma control under

74 treatment and multiple sensitizations are important parameters to define phenotypes of

75 asthma during childhood.

76 In this article we highlight the main results, which have emerged from these cohorts in

77 preschool then in school age wheezers

78 
80 (Table $\left.n^{\circ} 1\right)$ The Pollution and Asthma Risk an Infant Study (PARIS), a birth cohort

81 composed of 3500 full-term newborns recruited in five public Parisian maternity

82 hospitals in Paris and its close suburbs, described wheezer phenotypes ${ }^{24}$ : severe atopic

83 wheezers and non-atopic severe wheezers as well as a mild nonatopic wheezer

84 phenotype. Trousseau Asthma Program (TAP) cohorts are independent cohorts of

85 several hundred consecutive children explored in a cross-sectional and prospective

86 manner by unsupervised analysis. In a TAP cohort study of 551 early wheezers with

87 an average age of 18 months described similar asthma phenotypes by cluster

88 analysis: "Mild Episodic Viral Wheeze" (EVW) and "Atopic Multiple-Trigger" (AMT)

89 and "Non-atopic uncontrolled-wheeze" $(N A U W)^{14}$ (Fig 1). These phenotypes were

90 validated by another independent TAP cohort ${ }^{15}$ which also applied a new approach

91 including exhaled nitric oxide (FeNO) determinants together with severity and atopy

92 by cluster analysis. Furthermore

$93 E V W$ consisted of children with wheeze related to cold only, mild disease. These

94 findings are consistent with The Tucson Children's Respiratory Study. This birth

95 cohort is a long-term, longitudinal, prospective study of the risk factors for acute lower

96 respiratory tract illnesses in early childhood and for chronic obstructive airways

97 disease in later life. It includes 1,246 newborns enrolled between May 1980 and

98 January $1984^{25}$. For the first time these authors described early transient wheeze with

99 rare episodes of wheeze apart from colds in infancy compared to persistent

100 wheezers ${ }^{26}$. In the same manner, Spycher et $a l^{27}$. in two independent cohorts (nested

101 samples of total population of 1,650 white children recruited in 1990 at the age of $0-5$

102 years in Leicestershire, UK) showed a phenotype with mild, virus-triggered symptoms

103 wheeze. The AMT phenotype, includes more children with allergic diseases such as 
104 eczema, allergic rhinitis (AR) food allergy and more specific IgE positivity and a

105 higher proportion of elevated values for total IgE. This phenotype is associated with

106 severe wheezing disease, defined by a greater percentage of multiple trigger wheezes

107 (MTW). The AMT phenotype is comparable to phenotypes identified by using other

108 approaches. For example, in the Avon Longitudinal Study of Parents and Children

109 (ALSPAC) $^{6}$, a birth cohort in which the children of 14541 pregnancies were recruited

110 antenatally between 1990-92, two phenotypes characterized by early and

111 intermediate-onset of wheeze persisting during childhood were characterized by

112 allergy features (with skin prick test positivity) and severity of the disease (with

113 bronchial hyperesponsiveness and reduced lung function $)^{28}$. This description was also

114 confirmed across two independent cohorts of children previously described by

115 Spycher et $a l^{21}$. The TAP cohort found that more boys fell into the AMT group. This

116 might be related to the well-known association between male gender and allergic

117 diseases $^{2930}$. In a British birth cohort, The National Asthma Campaign Manchester

118 Asthma and Allergy Study (MAAS cohort) parents were screened at 'booking'

119 antenatal visits between October 1995 and July 1997. A total of 3,618 mothers and

1202,172 fathers underwent skin-prick testing and newborns were allocated to allergic risk

121 groups according to parental atopic status. The main result of this cohort was the

122 impact of early onset allergy on asthma prognosis. Effectively, Belgrave et al. ${ }^{31}$

123 showed that children with frequent asthma exacerbations and multiple early atopy are

124 at risk of a progressive loss of lung function from 3 to 11 years and this effect is also

125 more marked in boys.

126 NAUW was characterized mainly by moderate to severe disease and uncontrolled

127 wheeze despite high doses of ICS, a higher proportion of parental asthma and higher

128 ferritine values. This phenotype has been less described by other teams. However, 
129 Spycher et $a .^{21}$, showed an intermediate phenotype between the atopic persistent and

130 the viral wheeze phenotype in terms of prognosis in preadolescence.

131 Moreover, in the TAP cohort the NAUW phenotype was only encountered in girls.

132 Isozaki et al. ${ }^{32}$ demonstrated a gender difference in phenotypes with atopic wheezing

133 more frequently encountered in boys and non-allergic wheezing resistant to treatment

134 more prevalent in girls. This phenotype has been known for a long time in adults and

135 is described as 'Intrinsic asthma' with a female predominance though the aetiology is

136 still not understood ${ }^{33}$.

137 In the TAP cohort, with only two parameters related to atopy and asthma severity (i.e.

138 total $\operatorname{IgE}$ and asthma severity), $90 \%$ of boys and $83 \%$ of girls were assigned to the

139 appropriate cluster (Fig 2). This result underlines the impact of atopy but also of the

140 "intrinsic" aetiology in disease severity, with a higher percentage of boys in severe

141 atopic phenotypes and girls in severe non-atopic phenotypes.

143 Stability of asthma phenotypes in very young children during preschool age depends

$144 \quad$ on allergic expression (Table $\left.n^{\circ} 1\right)$

145 Several rules have been developed to predict whether preschool children will have

146 asthma at school age such as the stringent and loose forms of the Asthma Predictive

147 Index (API) in the Tucson Cohort ${ }^{34}$. The Prevention and Incidence of Asthma and

148 Mite Allergy (PIAMA) is a birth cohort study initiated in 1996 which enrolled

149 children born to allergic mothers in a double-blind placebo-controlled trial to evaluate

150 the use of mite-impermeable mattress and pillow covers ${ }^{35}$. In this cohort, the API

151 scores were externally validated with predictions comparable to the original Tucson

152 study. However, these prediction rules are difficult to apply in clinical practice

153 because of an overall low positive predictive value ${ }^{36}$. 
154 Another approach of the TAP cohort was to investigate if prospectively defined

155 phenotypes could have a different course during childhood and thus improve

156 prediction of the course of asthma (Fig 3$)^{17}$. This study revealed a good prognosis for

157 children classified as having the $E V W$ phenotype: at 5 years old $69 \%$ were still in the

$158 E V W$ group or were asymptomatic. This finding is in accordance with many other

159 studies which demonstrate that recurrent viral induced wheeze has a good prognosis

160 with a low risk of asthma ${ }^{37}$ or mild asthma. Spycher et al ${ }^{21}$ in particular noted that

161 despite mild symptoms in early life, children with transient wheeze were more likely

162 than controls to continue to have current wheeze and use bronchodilators in

163 preadolescence. This finding underlines the fact that remission

164 can occur in this phenotype, a fact which is important for the clinician in the

165 management of early wheezing.

166 The prognosis of the initial severe phenotypes (AMT and NAUW) is worse than for

$167 E V W$. This finding is in accordance with the notion of tracking asthma severity during

168 childhood $^{38}$. None of the children in the $A M T$ phenotype became asymptomatic at 5

169 years and more than half of $N A U W$ children were still severe at 5 years (Fig 3). This

170 poor prognosis of allergic asthma with early onset has already been described in

171 numerous prospective birth cohorts ${ }^{203940}$. The MAAS ${ }^{4142}$ demonstrated that atopy, and

172 especially early onset of multiple sensitizations, increases the risk of persistence of

173 asthma with severe exacerbations during childhood. In contrast, only Spycher et al. ${ }^{21}$

174 found a third wheeze phenotype in both their cohorts - identified as intermediate

175 between the atopic persistent and the viral wheeze phenotype - associated with a poor

176 prognosis in preadolescence similarly to the TAP findings for the NAUW group.

177 Possibly, this phenotype is associated with persistent wheezing during preschool and

178 school age in relation with late-onset atopy. 
179 More globally, the lesson to retain about prognosis of the early wheezer is that

180 changes observed in each initial phenotype in preschool aged children depend not only

181 on the expression of allergy but also on the time of onset (early or late). Finally,

182 although none of the phenotypes identified in the TAP corresponded to the GINA

183 definition of asthma severity, it is worth noting that their most recent guidelines ${ }^{43}$ have

184 approved a "phenotyping approach" in asthma management by referencing the TAP $185 \operatorname{article}^{17}$.

187 Asthma severity at school age depends on inflammatory cellular type (Table $n^{\circ} 1$ et $\left.188 n^{\circ} 2\right)$

189 Asthma in children is highly heterogeneous and is related not only to lung function 190 and atopy but also to systemic inflammation. Another TAP cohort recruited 309

191 children of school age and identified three independent clusters of asthma in a cluster

192 analysis applied to 15 variables $^{44}$.

193 The "Asthma with multiple allergic sensitizations" cluster was more atopic, with more

194 frequent severe exacerbations but relatively normal lung function. This type of severe

195 asthma is associated with an inflammation predominantly of "allergic type" (with 196 eosinophil and basophil cells) in combination with multiple allergic sensitizations and

197 elevated total IgE. Many studies, mainly in children, have confirmed that asthma at 198 risk of severe exacerbations or difficult to control is associated with allergic asthma ${ }^{45}$.

199 The "Severe asthma with bronchial obstruction" cluster was characterized by the 200 lowest lung function and more blood neutrophils, IgG and IgA but less atopy. The 201 children were also older and had a higher BMI. Other studies have shown an 202 association between the severity of asthma and neutrophilic inflammation detected by

203 induced sputum in particular in adult ${ }^{4647}$ The TAP results underline that neutrophilic 
204 asthma exists also in children with unknown aetiology $y^{38}$. This finding supports those

205 of the Epidemiological study on the Genetics and Environment of Asthma, bronchial

206 hyperresponsiveness and atopy (EGEA). The EGEA family sample consisted of 388

207 French nuclear families that included 253 families ascertained through offspring with

208 asthma (one offspring proband in $90 \%$ of families and two in the remainder) and 135

209 families ascertained through a parent with asthma. EGEA asthma phenotypes showed

210 that the phenotype of "active treated allergic childhood-onset asthma" is associated

211 with blood eosinophilia, while "active treated adult-onset asthma" is associated to

212 blood neutrophils" ${ }^{\prime 4}$. Another group linked inflammation to asthma severity. The

213 Severe Asthma Research Program (SARP) funded by the The National Heart, Lung,

214 and Blood Institute (NHLBI) recruited subjects with asthma of all ages who met the

215 ATS workshop definition of severe asthma. An additional group of subjects with

216 asthma that did not meet the criteria for severe asthma (not severe) was also studied. In

217 the same manner as in previous studies, a multivariate approach identified a severity

218 spectrum related to sputum cellular inflammation from mild-to moderate allergic

219 asthma with minimal or eosinophil predominant inflammation to moderate-to-severe

220 asthma with neutrophil-predominant or mixed granulocytic inflammation ${ }^{49}$.

221

\section{Allergic asthma is a heterogeneous disease (Table $\left.{ }^{\circ} 2\right)$}

223 Allergy expression defines the prognosis of asthma during childhood but the problem

224 is how should atopy be defined? Atopy depends on allergic sensitization (single or 225 multiple but also the type of allergen and the date of onset of sensitization) and the 226 association with allergic comorbidities (AR, eczema, food allergy).

227 In a recent article ${ }^{16}$, a TAP cohort study performed in 125 children of school age with 228 allergic asthma described four phenotypes. 
229 The "House dust mite (HDM) Sensitization and Mild Asthma" phenotype, 98\% of 230 whom were monosensitized and had mild asthma (74\% of cases). In a previous study, 231 we had described a similar phenotype of asthma with few allergic sensitizations and 232 mild asthma ${ }^{38}$. Moore et al. $^{50}$ also defined a large cluster (82\% of the study 233 population) of adults with early-onset mild atopic asthma. The Childhood Asthma

234 Prevention Study (CAPS) ${ }^{7}$ included pregnant women whose unborn children were at 235 high risk of developing asthma because of a parent or a sibling with a current 236 diagnosis of asthma or frequent wheeze recruited from the antenatal clinics of six

237 hospitals in Sydney, Australia. Six hundred and sixteen women were enrolled in the 238 main trial between September 1997 and December $1999^{51}$ Both the CAPS and MAAS 239 cohorts $^{30}$ as well as the TAP cohort defined an HDM monosensitized population which 240 confers a better prognosis of asthma than children with multiple sensitizations.

241 In the TAP cohort, the "Pollen Sensitization with Severe Exacerbations" phenotype

242 comprised $92 \%$ of children with severe exacerbations and pollen sensitization. Erbas 243 et al. $^{52}$ showed a linear increase in asthma emergency department presentations 244 correlated with an increased concentration of ambient grain of grass pollen $(\mathrm{p}<0.001)$.

245 More specifically, pollen-allergic children seem to be admitted due to food-induced 246 anaphylaxis more often during the pollen season $(\mathrm{p}=0.015)^{5354}$.

247 In the TAP cohort "Multiple Allergies and Severe Asthma" phenotype includes 248 children with a multiple allergic phenotype (100\% of the children had eczema and 249 multiple sensitizations) and higher values of $\operatorname{IgE}(1123 \mathrm{kU} / \mathrm{L})$ and FeNO (67 ppb).

250 Moreover, the severity of asthma is attested by the highest proportion of moderate to 251 severe asthma (95\%) and a significant decrease in $\mathrm{FEF}_{25-75}$. The clinical relevance of 252 FeNO in asthma severity was also identified in the PIAMA cohort ${ }^{55}$ and by Sonnappa $253 \mathrm{~S}$ et al $^{56}$ : FeNO measured at 8 years was associated with persistent, intermediate, and 
254 late-onset wheeze only in children with allergic sensitization at 8 years. The German

255 Multicentre Allergy Study (MAS) cohort consists of 1,314 children born in 1990 and

256 followed at the ages of 1, 3, 6, 12, 18, and 24 months and then at yearly intervals

257 thereafter until age 13 years ${ }^{57}$. This cohort found that eczema associated with filaggrin

258 loss-of-function mutations conveyed a greater risk of severe asthma phenotype with a

259 significant decrease in pulmonary function at puberty. Moreover, in accordance with

260 the TAP results, children (especially boys) with persistent wheeze, frequent asthma

261 exacerbations, and multiple early atopy in the MAAS cohort ${ }^{25}$ had diminished lung

262 function throughout childhood and were at higher risk of a progressive loss of lung

263 function from age 3 to 11 years. Furthermore, Garden et al. (the CAPS cohort) ${ }^{47}$

264 showed that asthma risk is related to the type of allergen sensitization, with a strong

265 association between the mixed food and inhalant sensitization class and poor asthma

266 control at age 8 years.

267 Finally the last phenotype discovered in the TAP cohort was the "Multiple Allergic

268 Sensitizations and Mild Asthma" phenotype, in which 97\% of the children had

269 multiple sensitizations and $100 \%$ mild asthma. Several reasons could explain this

270 novel result linking multiple sensitizations and mild asthma severity. Firstly, this

271 phenotype is associated with a low percentage of eczema and it is known that eczema

272 plus allergic asthma confers an intrinsically severe asthma. Secondly, multiple allergic

273 sensitizations could be related to biological sensitizations rather than to real allergy

274 explaining why total $\mathrm{IgE}$ and FeNO values were lower in this group.

275 To summarize, severe allergic asthma in children could consist of two phenotypes

276 depending on the type of sensitization and the association with other allergic

277 comorbidities: severe phenotype with acute exacerbations and related to pollens and/or 
278 food sensitizations and a severe phenotype with very high inflammatory markers

279 constantly associated with atopic dermatitis.

280

281 Asthma phenotypes and personalized medicine

282 The Childhood Asthma Management Program (CAMP) is a multicenter, randomized,

283 double-masked clinical trial designed to explore the clinical relevance of the clustering

284 approach in assessing the long-term effects of three inhaled treatments for mild to

285 moderate childhood asthma: budesonide (a glucocorticoid used daily) and albuterol (a

286 short-acting $\beta$-agonist bronchodilator used as needed); nedocromil (a nonsteroid anti-

287 inflammatory agent used daily) and albuterol; and placebo and albuterol ${ }^{11}$. Overall, in

288 this cohort Howrylak et al. ${ }^{58}$ found five reproducible patient clusters that could be

289 differentiated on the basis of atopic burden, degree of airway obstruction, and history

290 of exacerbation. Moreover, the clustering approach predicted long-term asthma control

291 as well as longitudinal differences in pulmonary function and response to long term

292 treatment.

294 Conclusions

295 As already suggested ${ }^{59}$, our analysis confirms that existing cohorts studies have 296 provided data useful for the ascertainment of early life asthma phenotypes. Further

297 studies should be designed to find noninvasive biological markers to better define

298 wheezing phenotypes in very young children associated with an elevated risk of 299 developing asthma to define personalized medicine based on targeted treatment. 
301 FIG 1: Representation of the three clusters according to the percentage of

302 Multiple Trigger Wheeze, Severity and Atopy for the entire population $(\mathbf{n}=551)$

303 MTW (Multiple Trigger Wheeze) is defined as wheezing during colds and with other

304 triggers such as house dust, grass, pets, tobacco smoke, exercise or cold air; Severity is

305 defined as percentage of moderate to severe asthma according to GINA classification;

306 Circled area represents the percentage of atopy defined as percentage of positive

307 Phadiatop Infant ${ }^{\circledR} \geq 0.35 \mathrm{U} / \mathrm{ml}$. (Ref 14$)$

309 FIG 2: Classification tree for entire population using two variables i.e. asthma

310 severity according to GINA classification and Phadiatop Infant ${ }^{\circledR}$

311 Subjects are assigned to the three clusters that range from milder recurrent wheeze

312 (Cluster 1) to more severe disease (Clusters 2 and 3) with $76 \%$ of the subject assigned

313 to the appropriate cluster. Tree performances are given. (Ref 14)

315 FIG 3: Change of wheeze phenotypes from under 3 years until 5 years of age

$316 \mathrm{Y}$ axis represents change (expressed in percentage) of separate 3 clusters towards the 4

317 clusters at 5 years of age. At 3 years of age : Mild EVW: Episodic Viral Wheeze

318 (wheezing only during colds and asymptomatic between episodes), Atopic MTW:

319 Multiple Trigger Wheeze (wheezing during colds and with other triggers such as

320 house dust, grass, pets, tobacco smoke, exercise or cold air), NAUW: Non-atopic

321 Uncontrolled Wheeze. The Fisher exact test rejects the independence assumption

$322 \quad(\mathrm{p}<0.001) .(\operatorname{Ref} 17)$ 
325 Table $\mathbf{n}^{\circ}$ 1: Asthma phenotypes in very young children

326

\begin{tabular}{|c|c|c|c|c|}
\hline & $\begin{array}{l}\text { Gender } \\
\text { Predominance }\end{array}$ & $\begin{array}{l}\text { High risk of } \\
\text { exacerbation }\end{array}$ & $\begin{array}{l}\text { Prognosis in term } \\
\text { of asthma } \\
\text { persistence during } \\
\text { childhood }\end{array}$ & $\begin{array}{l}\text { Predominant } \\
\text { inflammation } \\
\text { /Response to } \\
\text { corticosteroid }\end{array}$ \\
\hline $\begin{array}{l}\text { Mild Episodic Viral } \\
\text { Wheeze }\end{array}$ & Male $^{18}$ & No ${ }^{14,15,18}$ & Good $^{17,20,21,31}$ & $\begin{array}{l}\text { None }^{14} \\
\text { /High }^{14}\end{array}$ \\
\hline $\begin{array}{l}\text { Atopic Multiple- } \\
\text { Trigger }\end{array}$ & Male $^{14,21,25}$ & Yes $^{25,14,18}$ & $\begin{array}{l}\text { Poor }^{14,21,17,22,19,25,28,29} \\
33,34,35,36\end{array}$ & $\begin{array}{c}\text { Eosinophilic }^{14,18,15,19} \\
\text { /Intermediate }^{14}\end{array}$ \\
\hline $\begin{array}{l}\text { Nonatopic wheeze } \\
\text { phenotype }\end{array}$ & Female $^{14,26}$ & $\mathrm{No}^{14,18,15}$ & $\begin{array}{l}\text { Intermediate } \\
\text { (depending of late } \\
\text { onset of allergic } \\
\text { expression) }^{17,21}\end{array}$ & $\begin{array}{c}\text { Neutrophilic ? } \\
\text { /Low }^{14}\end{array}$ \\
\hline
\end{tabular}


330

\begin{tabular}{|c|c|c|c|c|c|}
\hline & $\begin{array}{c}\text { Gender } \\
\text { Predominance }\end{array}$ & $\begin{array}{c}\text { Age of } \\
\text { asthma } \\
\text { onset }\end{array}$ & $\begin{array}{l}\text { High Risk of } \\
\text { exacerbation }\end{array}$ & $\begin{array}{c}\text { Prognosis } \\
\text { in tem of lung } \\
\text { function decline }\end{array}$ & $\begin{array}{l}\text { Predominant } \\
\text { inflammation } \\
\text { /Response to } \\
\text { corticosteroid }\end{array}$ \\
\hline $\begin{array}{l}\text { House dust mite } \\
\text { Sensitization and Mild } \\
\text { Asthma }\end{array}$ & $\mathbf{M}$ & Early $^{16,46,30}$ & - & - & $\begin{array}{c}\text { Eosinophil } \\
\text { /High }^{16}\end{array}$ \\
\hline $\begin{array}{l}\text { Pollen Sensitization with } \\
\text { Severe Exacerbations" }\end{array}$ & $\mathbf{M}$ & Late $^{16}$ & Yes $^{16,39}$ & - & $\begin{array}{c}\text { Eosinophil }{ }^{16,46,47,48} \\
\text { /High }^{16}\end{array}$ \\
\hline Multiple Allergic & $\mathbf{M}$ & Early $^{16,25,38,51}$ & - & Poor $^{16,51,45}$ & \\
\hline $\begin{array}{l}\text { Sensitizations and } \\
\text { eczema associated with }\end{array}$ & & & & & $\begin{array}{c}\text { High Eosinophil } \\
16,38,49\end{array}$ \\
\hline Severe Asthma & & & & & /Low $^{16}$ \\
\hline $\begin{array}{l}\text { Multiple Allergic } \\
\text { Sensitizations and Mild } \\
\text { Asthma }\end{array}$ & $\mathbf{M}$ & Early $^{16}$ & - & - & $\begin{array}{c}\text { Eosinophil }^{16} \\
\text { /High }^{16}\end{array}$ \\
\hline $\begin{array}{l}\text { Severe asthma with } \\
\text { bronchial obstruction }\end{array}$ & $\mathbf{F}$ & $\begin{array}{l}\text { Late } \\
38,42,43,44\end{array}$ & - & Poor $^{43,44}$ & $\begin{array}{c}\text { Neutrophil }^{38} \\
\text { /Very low }^{38,42,44}\end{array}$ \\
\hline
\end{tabular}


1 Eder W, Ege MJ, von Mutius E. The asthma epidemic. $N$ Engl J Med 2006;355:2226-35.

${ }^{2}$ McCallister JW. Reslizumab and eosinophilic asthma: one step closer to phenotypedirected therapy? Am J Respir Crit Care Med 2011;184:1096-7.

${ }^{3}$ Phelan PD, Robertson CF, Olinsky A. The Melbourne Asthma Study: 1964-1999. J Allergy Clin Immunol. 2002 Feb;109(2):189-94.

${ }^{4}$ Anderson GP. Endotyping asthma: new insights into key pathogenic mechanisms in a complex, heterogeneous disease. Lancet 2008;372:1107-19.

${ }^{5}$ Busse WW, Morgan WJ, Gergen PJ, et al. Randomized trial of omalizumab (anti-IgE) for asthma in inner-city children. N Engl J Med 2011 ;364 : 1015-15.

${ }^{6}$ A plea to abandon asthma as a disease concept. Lancet 2006;368:705.

${ }^{7}$ Arshad SH, Stevens M, Hide DW. The effect of genetic and environmental factors on the prevalence of allergic disorders at the age of two years. Clin Exp Allergy 1993; 23: 504-511.

${ }^{8}$ Bergmann RL, Bergmann KE, Lau-Schadendorf S, Luck W, Dannemann A, Bauer CP. Atopic diseases in infancy. The German multicenter atopy study (MAS-90) Pediatr Allergy Immunol. 1995; 5:19-25.

${ }^{9}$ Custovic A, Simpson BM, Murray CS, Lowe L, Woodcock A. The national asthma campaign manchester asthma and allergy study. Pediatr Allergy Immunol 2002; 13: 32-37.

${ }^{10}$ Brunekreef B, Smit J, de Jongste J, Neijens H, Gerritsen J, Postma D, Aalberse R, Koopman L, Kerkhof M, Wilga A, van Strien R. The prevention and incidence of asthma and mite allergy (PIAMA) birth cohort study: design and first results. Pediatr Allergy Immunol. 2002; 13: 55-60.

${ }^{11}$ Clarisse B, Nikasinovic L, Poinsard R, Just J, Momas I. The Paris prospective birth cohort study: which design and who participates? Eur J Epidemiol. 2007; 22: 203-210.

${ }^{12}$ Boyd A, Golding J, Macleod J, Lawlor DA, Fraser A, Henderson J, Molloy L, Ness A, Ring S, Davey Smith G. Cohort Profile: the 'children of the 90s'-the index 
offspring of the Avon Longitudinal Study of Parents and Children. Int $\mathbf{J}$ Epidemiol 2013; 42: 111-127.

${ }^{13}$ Mihrshahi S, Peat J, Webb K, Tovey E, Marks G, Mellis C, Leeder SR. The Childhood Asthma Prevention Study (CAPS): design and research protocol of a large randomised trial of the primary prevention of asthma. Control Clin Trials 2001; 22:333-54.

14 Spycher BD, Silverman M, Pescatore AM, Beardsmore CS, Kuehni CE. Comparison of phenotypes of childhood wheeze and cough in 2 independent cohorts $\mathbf{J}$ Allergy Clin Immunol 2013; 132: 1058-1067.

15 Hovland V, Riiser A, Mowinckel P, Carlsen KH, Lødrup Carlsen KC. The significance of early recurrent wheeze for asthma outcomes in late childhood. Eur Respir J. 2013; 41: 838-845.

16 Kauffmann F, Dizier MH. EGEA (Epidemiological study on the Genetics and Environment of Asthma, bronchial hyperresponsiveness and atopy)-design issues. EGEA Co-operative Group. Clin Exp Allergy. 1995; 25: 19-22.

17 The Childhood Asthma Management Program (CAMP): design, rationale, and methods. Childhood Asthma Management Program Research Group. Control Clin Trials. 1999; 20: 91-120.

${ }^{18}$ Dolan CM, Fraher KE, Bleecker ER, Borish L, Chipps B, Hayden ML, Weiss S, Zheng B, Johnson C, Wenzel S; TENOR Study Group. Design and baseline characteristics of the epidemiology and natural history of asthma: Outcomes and Treatment Regimens (TENOR) study: a large cohort of patients with severe or difficult-to-treat asthma. Ann Allergy Asthma Immunol. 2004; 92: 32-39.

19 American Thoracic Society Workshop. Proceedings of the ATS workshop on refractory asthma: current understanding, recommendations, and unanswered questions. Am J Respir Crit Care Med 2000;162: 2341-2351. 
${ }^{20}$ Just J, Gouvis-Echraghi R, Couderc R, Guillemot-Lambert N, Saint-Pierre P. Two novel severe wheezy young children phenotypes: boys atopic multiple-trigger and girls non-atopic uncontrolled wheeze. J Allergy Clin Immunol 2012; 130: 103-110.

${ }^{21}$ Gouvis-Echraghi R, Saint-Pierre P, Besharaty AA, Bernard A, Just J.Exhaled nitric oxide measurement confirms 2 severe wheeze phenotypes in young children from the Trousseau Asthma Program. J Allergy Clin Immunol. 2012; 130:1005-1007.

${ }^{22}$ Just J, Saint-Pierre P, Gouvis-Echraghi R, Laoudi Y, Roufai L, Momas I, Annesi Maesano I.Childhood allergic asthma is not a single phenotype. J Pediatr. 2014; 164 : 815-820.

${ }^{23}$ Just J, Saint-Pierre P, Gouvis-Echraghi R, Boutin B, Panayotopoulos V, Chebahi N, Ousidhoum-Zidi A, Khau CA. Wheeze phenotypes in young children have different courses during the preschool period. Ann Allergy Asthma Immunol. 2013; 111: 256261.

${ }^{24}$ Herr M, Just J, Nikasinovic L, Foucault C, Le Marec AM, Giordanella JP, Momas I. Risk factors and characteristics of respiratory and allergic phenotypes in early childhood. J Allergy Clin Immunol 2012; 130:389-96.

${ }^{25}$ Taussig LM, Wright AL, Morgan WJ, Harrison HR, Ray CG, Group Health Medical Associates. The Tucson Children's Respiratory Study. I. Design and implementation of a prospective study of acute and chronic respiratory illness in children. Am J Epidemiol 1989;129: 1219-1231.

${ }^{26}$ Martinez FD, Wright AL, Taussig LM, Holberg CJ, Halonen M, Morgan WJ. Asthma and wheezing in the first six years of life. N Engl J Med 1995; 332: 133-138.

${ }^{27}$ Spycher BD, Silverman M, Brooke AM, Minder CE, Kuehni CE. Distinguishing phenotypes of childhood wheeze and cough using latent class analysis. Eur Respir J. 2008; 31: 974-81.

${ }^{28}$ Henderson J, Granell R, Heron J, Sherriff A, Simpson A, Woodcock A, Strachan DP, Shaheen SO, Sterne JA. Associations of wheezing phenotypes in the first 6 years of 
life with atopy, lung function and airway responsiveness in mid-childhood. Thorax 2008; 63: 974-980.

${ }^{29}$ Mandhane PJ, Greene JM, Cowan JO, Taylor DR, Sears MR. Sex differences in factors associated with childhood- and adolescent-onset wheeze. Am J Respir Crit Care Med 2005; 172: 45-54.

30 Sears MR, Burrows B, Flannery EM, Herbison GP, Holdaway MD. Atopy in childhood. I. Gender and allergen related risks for development of hay fever and asthma. Clin Exp Allergy 1993; 23: 941-948.

${ }^{31}$ Belgrave DC, Buchan I, Bishop C, Lowe L, Simpson A, Custovic A. Trajectories of lung function during childhood. Am J Respir Crit Care Med. 2014; 189: 1101-1109.

${ }^{32}$ Isozaki A, Shoda T, Mimura S, Ogawa N, Noma T, Kawano T, Nakamura Y, Kawano Y. A trial of hierarchical cluster analysis of hospitalized wheezy infants and young children based on clinical factors. Arerugi 2011; 60: 586-592.

${ }^{33}$ Rackemann FM, Mallory TB. Intrinsic Asthma. Trans Am Clin Climatol Assoc 1941; 57: 60-73.

${ }^{34}$ Jose A. Castro-Rodriguez, Lorena Cifuentes, Carlos E. Rodríguez-Martínez. The asthma predictive index remains a useful tool to predict asthma in young children with recurrent wheeze in clinical practice Journal of Allergy and Clinical Immunology 2011; 127: 1082-1083.

35 Leonardi NA, Spycher BD, Strippoli MP, Frey U, Silverman M, Kuehni CE. Validation of the Asthma Predictive Index and comparison with simpler clinical prediction rules. J Allergy Clin Immunol 2011; 127: 1466-1472.

${ }^{36}$ Matricardi PM, Illi S, Keil T, Wagner P, Wahn U, Lau S. Predicting persistence of wheezing: one algorithm does not fit all. Eur Respir J 2010;35:701-3.

${ }^{37}$ Piippo-Savolainen E, Korppi M. Wheezy babies--wheezy adults? Review on longterm outcome until adulthood after early childhood wheezing. Acta Paediatr 2008; 97 : $5-11$ 
${ }^{38}$ Stern DA, Morgan WJ, Wright AL, Guerra S, Martinez FD. Poor airway function in early infancy and lung function by age 22 years: a non-selective longitudinal cohort study.Lancet. 2007; 370(9589):758-64.

${ }^{39}$ Illi S, von Mutius E, Lau S, Niggemann B, Gruber C, Wahn U. Perennial allergen sensitisation early in life and chronic asthma in children: a birth cohort study. Lancet 2006; 368:763-70.

${ }^{40}$ Kusel MM, Kebadze T, Johnston SL, Holt PG, Sly PD. Febrile respiratory illnesses in infancy and atopy are risk factors for persistent asthma and wheeze. Eur Respir J. 2012;39(4):876-82.

${ }^{41}$ Simpson A, Tan VYF, Winn J, Svensén M, Bishop CM, Heckerman DE, Buchan I, Custovic A. Beyond atopy: multiple patterns of sensitization in relation to asthma in a birth cohort study. Am J Respir Crit Care Med 2010; 181:1200-1206.

${ }^{42}$ Lazic N, Roberts G, Custovic A, Belgrave D, Bishop CM, Winn J, Curtin JA, Hasan Arshad S, Simpson A.Multiple atopy phenotypes and their associations with asthma: similar findings from two birth cohorts. Allergy. 2013; 68: 764-70.

${ }^{43}$ From the Global Strategy for Asthma Management and Prevention, Global Initiative for Asthma (GINA) 2009. Available from: http://www.ginasthma.org, Date last update june 9 2014. Date last accessed June 92014

${ }^{44}$ Just J, Gouvis-Echraghi R, Rouve S, Wanin S, Moreau D, Annesi-Maesano I. Two novel, severe asthma phenotypes identified during childhood using a clustering approach. Eur Respir J 2012; 40: 55-60.

${ }^{45}$ Carroll WD, Lenney W, Child F, Strange RC, Jones PW, Whyte MK, Primhak RA, Fryer AA. Asthma severity and atopy: how clear is the relationship? Arch Dis Child 2006; 91: 405-409.

${ }^{46}$ Wang F, He XY, Baines KJ, Gunawardhana LP, Simpson JL, Li F, Gibson PG. Different inflammatory phenotypes in adults and children with acute asthma. Eur Respir J 2011; 38: 567-574. 
47 The ENFUMOSA cross-sectional European multicentre study of the clinical phenotype of chronic severe asthma. European Network for Understanding Mechanisms of Severe Asthma. Eur Respir J 2003; 22: 470-477.

${ }^{48}$ Siroux V, Basagaña X, Boudier A, Pin I, Garcia-Aymerich J, Vesin A, Slama R, Jarvis D, Anto JM, Kauffmann F, Sunyer J. Identifying adult asthma phenotypes using a clustering approach. Eur Respir J. 2011; 38: 310-317.

${ }^{49}$ Moore WC, Hastie AT, Li X, Li H, Busse WW, Jarjour NN, Wenzel SE, Peters SP, Meyers DA, Bleecker ER; National Heart, Lung, and Blood Institute's Severe Asthma Research Program. Sputum neutrophil counts are associated with more severe asthma phenotypes using cluster analysis.J Allergy Clin Immunol. 2014; 133: 1557-1563.

${ }^{50}$ Moore WC, Meyers DA, Wenzel SE, Teague WG, Li H, Li X, D'Agostino R Jr, Castro M, Curran-Everett D, Fitzpatrick AM, Gaston B, Jarjour NN, Sorkness R, Calhoun WJ, Chung KF, Comhair SA, Dweik RA, Israel E, Peters SP, Busse WW, Erzurum SC, Bleecker ER; National Heart, Lung, and Blood Institute's Severe Asthma Research Program. Identification of asthma phenotypes using cluster analysis in the Severe Asthma Research Program. Am J Respir Crit Care Med 2010; 181: 315-323.

${ }^{51}$ Garden FL, Simpson JM, Marks GB; CAPS Investigators. Atopy phenotypes in the Childhood Asthma Prevention Study (CAPS) cohort and the relationship with allergic disease: clinical mechanisms in allergic disease. Clin Exp Allergy. 2013; 43: 633-641.

${ }^{52}$ Erbas B, Akram M, Dharmage SC, Tham R, Dennekamp M, Newbigin E, Taylor P, Tang ML, Abramson MJ. The role of seasonal grass pollen on childhood asthma emergency department presentations. Clin Exp Allergy 2012; 42: 799-805.

53 Vetander M, Helander D, Flodström C, Ostblom E, Alfvén T, Ly DH, Hedlin G, Lilja G, Nilsson C, Wickman M. Anaphylaxis and reactions to foods in children--a population-based case study of emergency department visits. Clin Exp Allergy 2012; 42: $568-577$.

${ }^{54}$ Katelaris $\mathrm{CH}$. Food allergy and oral allergy or pollen-food syndrome. Curr Opin Allergy Clin Immunol 2010; 10: 246-251. 
55 van der Valk RJ, Caudri D, Savenije O, Koppelman GH, Smit HA, Wijga AH, Postma DS, Kerkhof M, Brunekreef B, de Jongste JC. Childhood wheezing phenotypes and FeNO in atopic children at age 8. Clin Exp Allergy. 2012; 42: 13291336.

${ }^{56}$ Sonnappa S, Bastardo CM, Saglani S, Bush A, Aurora P. Relationship between past airway pathology and current lung function in preschool wheezers. Eur Respir J. 2011; 38: 1431-1436.

${ }^{57}$ Marenholz I, Kerscher T, Bauerfeind A, Esparza-Gordillo J, Nickel R, Keil T, Lau S, Rohde K, Wahn U, Lee YA. An interaction between filaggrin mutations and early food sensitization improves the prediction of childhood asthma. J Allergy Clin Immunol 2009; 123: 911-916.

58 Howrylak JA, Fuhlbrigge AL, Strunk RC, Zeiger RS, Weiss ST, Raby BA; Childhood Asthma Management Program Research Group. Classification of childhood asthma phenotypes and long-term clinical responses to inhaled anti-inflammatory medications. J Allergy Clin Immunol. 2014; 133: 1289-1300.

59 Bousquet J, Gern JE, Martinez FD, Anto JM, Johnson CC, Holt PG, Lemanske RF Jr, Le Souëf PN, Tepper RS, von Mutius ER, Arshad SH, Bacharier LB, Becker A, Belanger K, Bergström A, Bernstein DI, Cabana MD, Carroll KN, Castro M, Cooper PJ, Gillman MW, Gold DR, Henderson J, Heinrich J, Hong SJ, Jackson DJ, Keil T, Kozyrskyj AL, Lødrup Carlsen KC, Miller RL, Momas I, Morgan WJ, Noel P, Ownby DR, Pinart M, Ryan PH, Schwaninger JM, Sears MR, Simpson A, Smit HA, Stern DA, Subbarao P, Valenta R, Wang X, Weiss ST, Wood R, Wright AL, Wright RJ, Togias A, Gergen PJ. Birth cohorts in asthma and allergic diseases: report of a NIAID/NHLBI/MeDALL joint workshop. J Allergy Clin Immunol. 2014; 133: 15351546. 


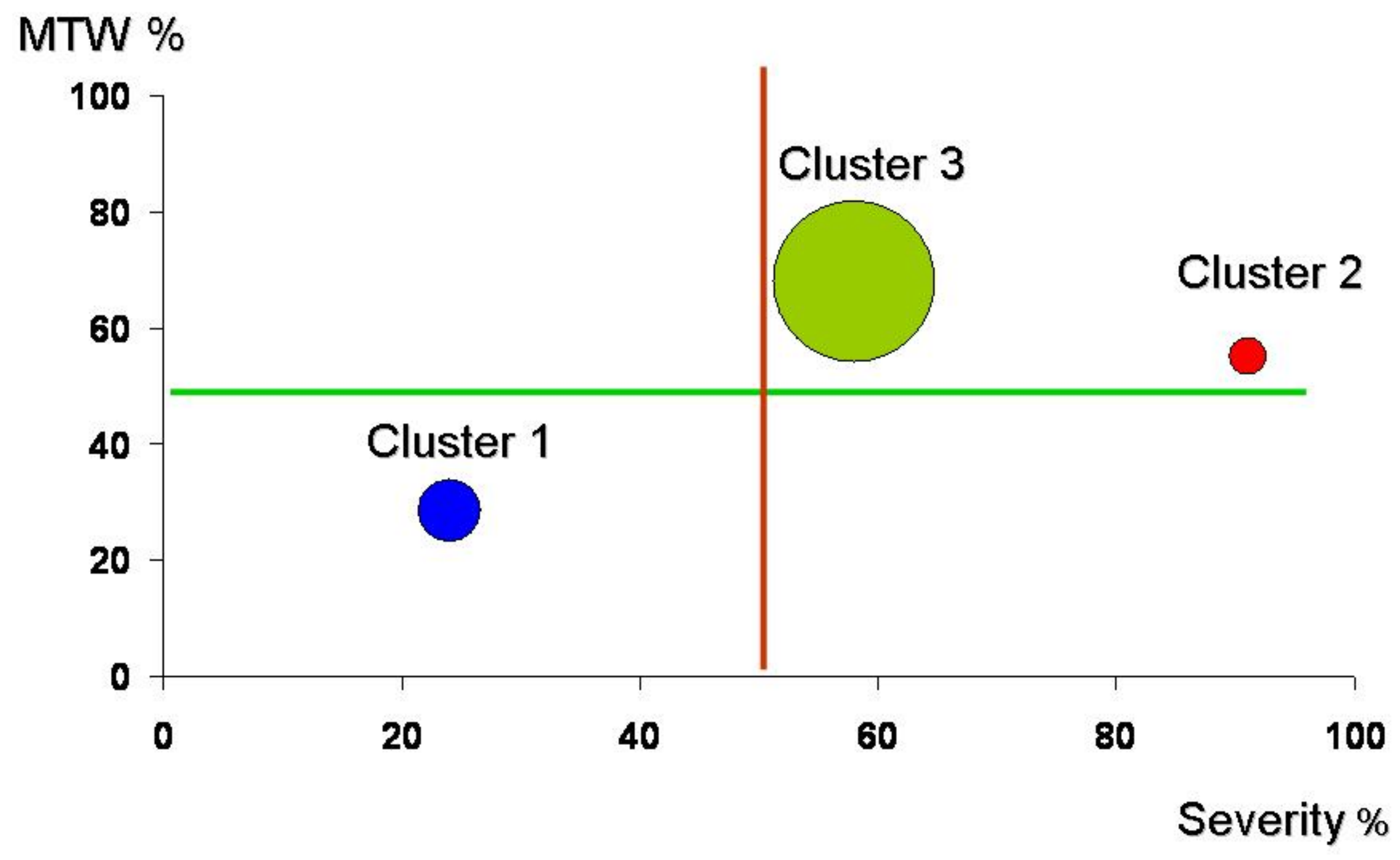

Fig. 1 
Asthma Severity

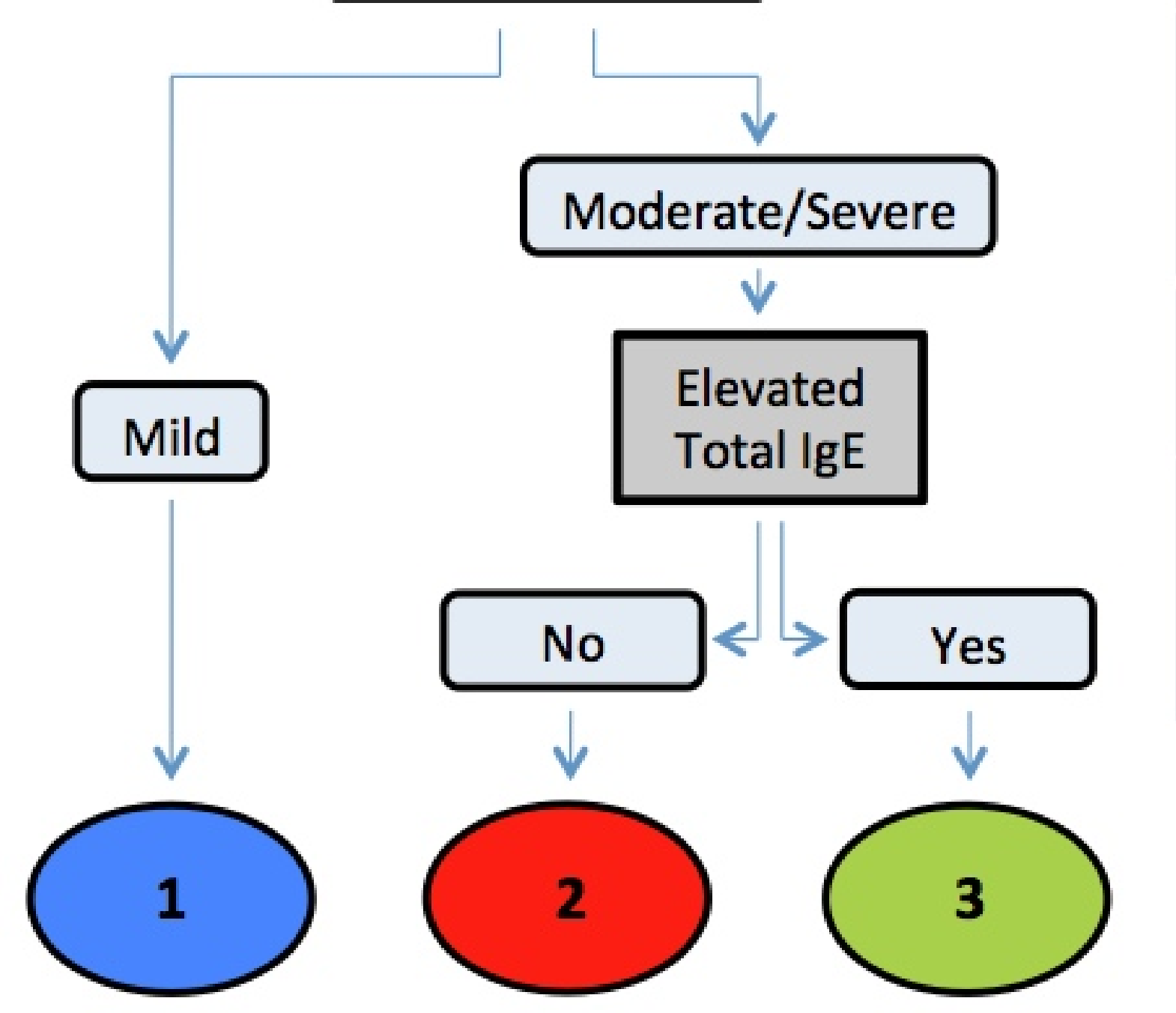

\section{Population}

\begin{tabular}{|l|l|l|l|l|}
\hline $\bar{\Xi}$ & 1 & 70 & 10 & 0 \\
\hline
\end{tabular}

\begin{tabular}{|l|l|l|l|l|}
\hline \multirow{J}{*}{} & 2 & 1 & 53 & 1
\end{tabular}

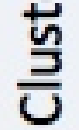

3

14

Prediction

Percentage

1

2

3

\begin{tabular}{|l|l|l|l|l|}
\hline $\bar{\Xi}$ & 1 & 0.88 & 0.12 & 0 \\
\hline
\end{tabular}

\begin{tabular}{|l|l|l|l|l|}
\hline \multirow{2}{*}{$\frac{\pi}{4}$} & 2 & 0.02 & 0.96 & 0.02 \\
\hline
\end{tabular}

\begin{tabular}{|l|l|l|l|l|}
\hline \multirow{U}{*}{$\mathrm{S}$} & 3 & 0.44 & 0.06 & 0.5 \\
\hline
\end{tabular}

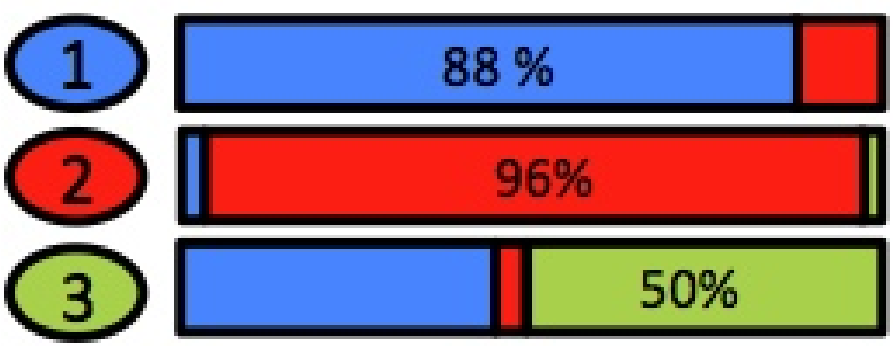




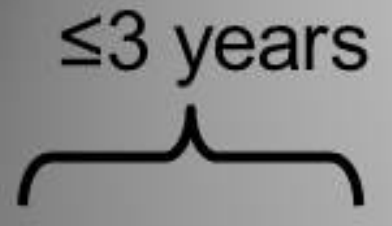

EVW

$n=93$

\section{NAUW}

$n=34$

\section{AMTW}

$n=23$
"Asthma in Remission" and "Mild EVW" $n=85$ years

$33 \%$

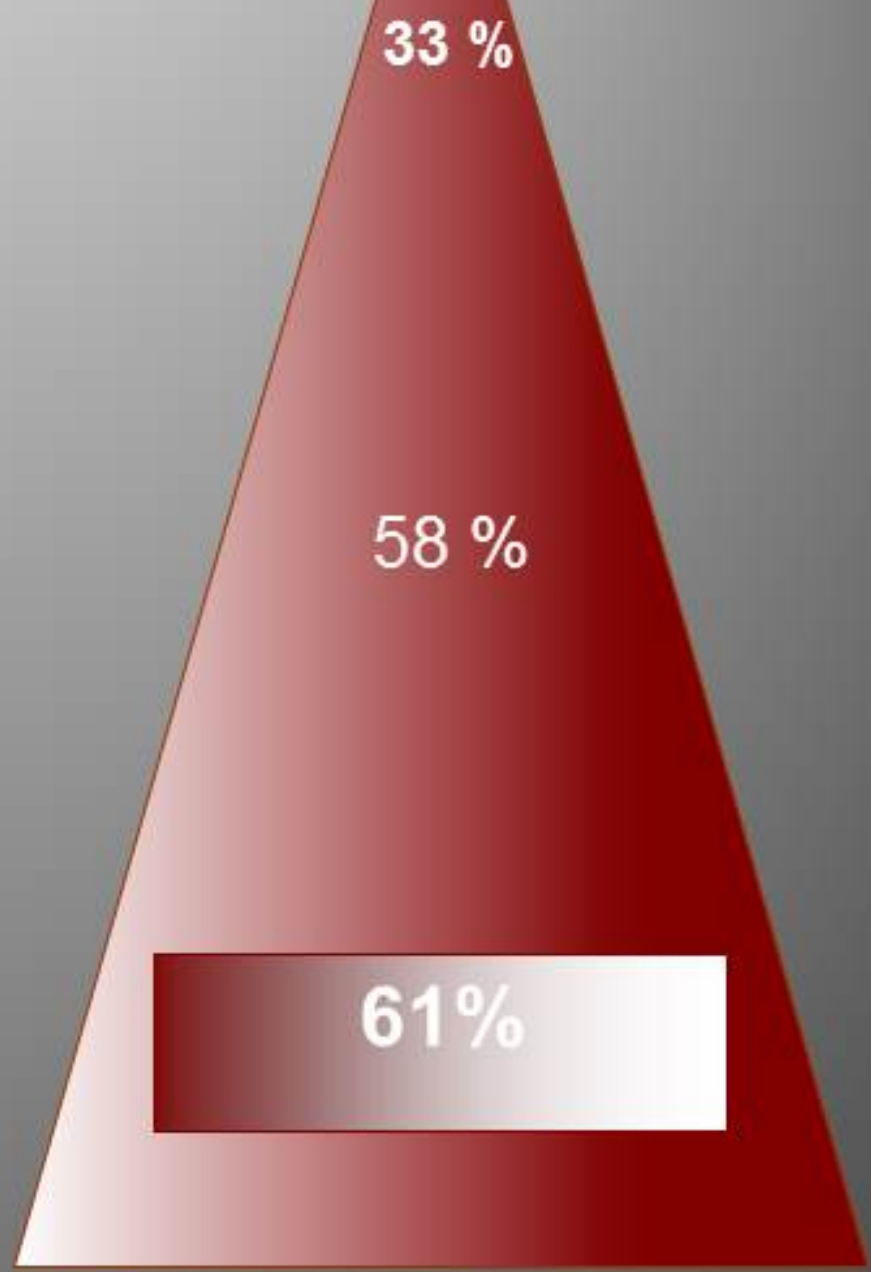

"Allergic Moderate to Severe Asthma"

$n=65$ 